\title{
Efficiency in Public Administration Focusing on Strategic Alignment
}

\author{
José Carlos de Souza Colares ${ }^{1}$, Henrique de Castro Neves ${ }^{2}$, Jean Carlo Silva dos Santos ${ }^{3}$, Márcio José Matias \\ Cavalcante $^{3}$, Rosangela Aparecida da Silva ${ }^{4} \&$ Flavio de São Pedro Filho ${ }^{5}$ \\ ${ }^{1}$ Public Finance and State Administration, Universidad Nacional de La Matanza, Buenos Aires, Argentina \\ ${ }^{2}$ Business Administration, Universidad Nacional de La Matanza, Buenos Aires, Argentina \\ ${ }^{3}$ UFRGS-EA, Brazil \\ ${ }^{4}$ Faculdade União das Escolas Superiores de Rondônia-UNIRON-UNIRON, Brazil \\ ${ }^{5}$ Management and Economics, University of Beira Interior (UBI), Brazil \\ Correspondence: José Carlos de Souza Colares, Postgraduate Program in Economic Sciences, Public Finance and \\ State Administration, Universidad Nacional de La Matanza, Buenos Aires, Argentina.
}

Received: July 1, 2020

doi:10.5430/ijba.v11n5p58
Accepted: August 3, 2020

Online Published: September 13, 2020

URL: https://doi.org/10.5430/ijba.v11n5p58

\begin{abstract}
The purpose of this article is to measure the efficiency of Public Administration in the process of strategic alignment of people management with strategic organizational guidelines. The strategic alignment of Human Resources consists on adapting the people management strategy to the organization's strategy. An efficient institutional strategic alignment with the people management area is an essential condition for the success of the business. The first point for people management to be aligned with the organizational strategy regards to the fact that the human resources management strategy must derive from the corporate strategic plan. Recent studies demonstrate that there is an important change in the strategic focus related to people management, with the transition from a strategy focused on control to a strategy linked to commitment standing out as the most significant change. This article was developed through a bibliographic study on the strategic management of people in public administration and, also, by conducting a field research that covered 20 (twenty) units of the administrative structure from the government of the state of Rondônia - Brazil. The method used was the case study supported by a mathematical model developed by the authors, aiming to evaluate the event qualitatively and quantitatively in a more profound manner. The results demonstrated that the actions of the Public Administration, regarding the strategic alignment of the Human Resources area with the organizational strategy, are at an inadequate level of efficiency.
\end{abstract}

Keywords: administration, alignment, efficiency, people management, human resources, strategic planning

\section{Introduction}

The development of the Human Resources management model evolved at an accelerated rate, mainly in the post-industrial revolution period. The Human Resources area has ceased to be a mere department that takes care of personnel documentation to become a key part of organizational success. The globalized world has forced the organizations to rethink the model of traditional management, requiring from the enterprise investments in technology, structure and, especially, in human resource management. In the latter case, the challenge is to transform the people management area into a strategic sector able to provide elements capable of boosting results in the various departments of the organization.

In the theoretical field, several chains have been defending the idea that the human being must be raised to the position of strategic partner of the organization. In this sense, qualifying as a simple employee of the company or even an employee of the organization would no longer make sense and, to this end, the human resources area must use the most diverse forms, methods and models to make the maximum of the set of skills that emerges from people. It is possible to affirm aprioristically that this scenario forced the institutions to undergo a true metamorphosis in order to adapt to the new paradigms in terms of people management. At this juncture, private organizations have shaped their administrative models to highlight the aspects of competitiveness and survival while, that, the public organizations have turned to improving the quality of services provided to the society. 
It is known that, in relation to the public service, there is a legal obligation to inform the society not only about the results achieved, but also regarding the form or the means used to reach it, in order to enable citizens to know how the resources are being used and define whether the adopted model meets the expected public interest. This requirement also applies to the people management processes in public organizations.

In this sense, this study focuses on two main challenges, namely: to develop ways to measure quantitatively and qualitatively the contribution of human resources policies and practices on the results of the organization (a), and to point out the repercussions this represents for society (b).

\section{Research Problem and Objectives}

The research problem is to identify whether the public agencies surveyed promote the alignment of the people management with strategic organizational planning. This is the way in which it seeks to interpret the level of efficiency of these Public Units in conducting this model, in view of the vital significance of measuring this efficiency in order to know whether the services provided by public organizations can be considered as effectual and effective. As a result, it is worth asking the following key question: What is the level of efficiency of the human resources strategic alignment model with the organizational strategy adopted by public administration in the surveyed bodies?

To respond the research question, is proposed as the general objective to measure the efficiency of Public Administration in the process of strategic alignment of people management with organizational strategic guidelines; and as specific objectives (1) to verify if the public administration of the State of Rondônia adopts the model of strategic alignment of personnel management; (2) to identify the level of efficiency of the actions of public administration to promote the strategic alignment of human resources management to the organizational strategic planning; and (3) to indicate whether the human resources management practices exercised by the public administration are appropriate to the organizational strategic alignment process. Given these objectives, it is expected to understand if the practices are being properly exercised by the public administration, based on the sample selected in this research.

\section{Theoretical Review}

In this topic, the main ideas and conceptual conceptions aimed at providing theoretical support for this paper are presented, regarding the understanding of Human Resources management, organizational strategy and strategic alignment. This front will make it possible to deal theoretically with the theme, in the search for a better understanding of the subject and, thus, obtain the bases for the proposal of a structure for verifying the efficiency index in the investigated organizations to then achieve the research objective.

\subsection{Strategy Concepts and Strategic Alignment}

The concepts of strategy and strategic alignment are widely debated in the administration area, which can be defined as the profiling of strengths and weaknesses, environmental threats and opportunities where the organization operates. They allow to define ways to maximize forces, to minimize even to suppress the weak points, to find suitable means to face threats and to promote the maximum use of opportunities, as prescribed by Andrews (1971).

\subsubsection{Conception About Strategy}

Herrero Filho (2018) notes that the achievement of the organizational objectives of countries and even individuals necessarily involves the design of an efficient strategy. A solid tactic prevents companies from being held hostage by conditions involving organizational environments, such as marketing, competition, services, scarce resources, lack of creativity and motivation, among other circumstances. Therefore, it is necessary that managers use correct methodologies, adequate tools and invest in the continuous learning of their collaborators, so that the strategy design is efficient enough to achieve the desired results.

Collis (1996) adds that the strategy is linked to the uncertainty provided by the company's operating environment. In this case, the strategic work of the administrators must be focused on minimizing uncertainties through an understanding of the internal and external operating environment that will provide the most reasonable means of reducing doubts and the best way to use the available resources. Such an understanding may lead the organization to operate differently and obtain superior performance among its competitors, which contributes to its survival.

\subsubsection{Conception About Strategic Alignment}

Concerning strategic alignment, it deserves to bring the conception of Peteraf and Reed (2007) and from Silveira (2015), according to which it is an essential condition that provides a positive development of the institution, since the technique allows to adjust the demands to the organizational interactions. This approach includes issues related to 
the products and strategic contributions of the area, involved in the alignment process and in its performance as a strategic partner. Also involve other issues such as the level of excellence in operations, the development of human resources and the respective social accountability. These elements must be inserted in the relations with the micro and macro environment in the pursuit of obtaining high performance and gains related to competitive advantage.

Kaplan e Norton (2017) prescribe that in defining a strategy, it must be ensured that all sectors are aware of what was planned and, more than that, that they are following the plans. For the authors, the disconnection of the purposes leads the employees to seek discrepant objectives, incompatible with the previously defined strategic guidelines. Therefore, it is necessary to have an organizational alignment supported by a set of practices able to lead the organization to reach the objectives, which can be achieved through the application of the balanced scorecard technique, a methodology that allows to establish performance indicators in an aligned way creating a bridge between the mission and the organizational strategy aimed at ensuring the achievement of the vision of the future in an aligned and coherent way among all sectors of the company.

Henderson and Venkatraman (1996) note that an efficient alignment of the strategic plan promotes the incorporation of all components of the business environment in a single set. In other words, a correct alignment provides an understanding of what is perceived in the internal and external environments, which facilitates the development of personal and organizational skills, allowing to maximize results. The authors state that the concept of strategic alignment can be seen in two aspects: the economic and the system model adopted in the organization. The first is linked to the leadership's ability to accommodate existing resources in order to support strategic projects, making them feasible. The second would require the organization to adopt the open system model, where the synergistic exchange of energy and matter with the surrounding environment enables dynamic strategic adjustment and allows the organization to adapt to constant changes in the business environment.

The alignment will be consolidated the when the mission defined by senior management is in line with organizational actions and strategic intentions through the intervention of the people, structure and systems. Thus, it can be concluded that there will be strategic alignment when the main strategic objective is reached in a coherent manner by the other organizational levels, as specified Labovitz and Rosansky (1997).

\subsection{People Management Concepts}

For Fleury and Fisher (1998) the approach to people management consists of a set of principles and experiences defined by the senior management in order to guide human behaviour and interpersonal relationships in the work circle. For these authors, the term replaced the wording Human Resource Management that was used to define the way to manage people in organizations.

The Society for Human Resource Management - SHRM (2007), defines the term people management as a set of policies designed to describe, plan, measure and evaluate the practices, initiatives and actions aimed for the development of people and the impact of their activities on organizational results. For this Association, these measures aim to boost the employees' commitment to the organization's objectives, including regarding socio-environmental responsibility.

França (2007) asserts that people management transcends merely notary tasks, expanding to the emerging models of the digital age that have shaped new paradigms in the management of organizations. Thus, to traditional activities such as recruitment, selection, development, among others, concepts such as quality, cultural change, technological skills, citizenship, career, etc. were added. Those requirements have transformed the traditional model of human resources into an inter-organizational enterprise that, if well managed, is capable of boosting the results projected by the company.

\subsection{Definitions on Strategic Alignment of Human Resources}

The understanding of the concept of strategic alignment in the human resources area stands out as a relevant point for this research. The understanding of this concept is useful because it underlies theoretical knowledge essential to the elucidation of the issues related to the strategy on efficiency, from the examination of the alignment of activities that can be taken to demonstrate that the sector of human resources can undertake efficient actions in the search for effectual and effective results of interest to the organization and stakeholders.

\subsubsection{Human Resources Management as a Catalyst for Strategic Effort}

For Bergue (2019), human resources management must assume the centrality of production by concentrating, in itself, a substantial part of the generation of value in organizations. Wherefore, for the author, it must be strategic and integrated to the point of serving as a basis to provide in a systemic way the strategic alignment between the 
guidelines established at the summit and the people in charge of implementing them. For the author, human resource management must be articulated with at least three dimensions, namely: the functional view (organization area) the process view (managerial) and the centrality of organizational appreciation, corresponding to the responsibility of people in the design and development of strategies, as well as on their results.

Albuquerque (2009) advocates that the strategic alignment of human resources consists of adapting the people management strategy to the organizational strategy. The first point for the strategic alignment of people management at the institutional level is that the strategic plans for human resource management must derive from the organization's corporate strategy. Recent studies demonstrate that there is an important change in the strategic focus related to people management, with the transition from a strategy focused on control to a strategy linked to commitment standing out as the most significant change. In this direction, the human resources area should assume the role of catalyst for strategic business planning efforts. To this end, it is understood that the person who leads the human resources sector must occupy some top management position, with powers to participate directly in strategic business definitions. An efficient institutional strategic alignment with the people management area is an essential condition for the organization's success, as prescribed by Albuquerque (2009).

Albuquerque (2009) recommends that, in order to align the people management strategy to organizational strategy, it is necessary for the company to undertake the selection by competences, aimed at recruiting and hiring new talent based on the definition of a required competency profile for each position. Such a procedure must necessarily be directed by the human resources area. Once this transition is made, the ground for strategic alignment between the people management area and the business strategy will be paved.

\subsubsection{Contributions of the People Management Area to the Organizational Strategic Alignment}

Becker, Huselid and Hurich (2001) recommend that, in order to ensure alignment between corporate strategy and human resources policy, it is necessary to profile the vision of the corporate business with the understanding and commitment of this vision by the people involved. This commitment must be evidenced by effective contributions from the human resources area that are aligned with the organizational strategy. In addition, the mission and analysis of the human resources environment must be in line with the organization's mission and with the analysis of the organizational environment. It is interesting to note that the strategic initiatives must be correlated with the critical success factors and the selection and development of organizational strategy. For instance: the human resources area must contribute to projects aimed at extolling the company's name. Such assumptions demonstrate that the area is in line with the organizational strategy. With these elements levelled, it can be understood that people management would be aligned with the organization's strategic planning.

Antunes and Martins (2005) recommend that the people management are should provide products and strategic contributions, such as: (I) hiring new talents through selection of competencies; (II) contribution to cost reduction processes; and (III) projects that enhance the name of the institution. These products would demonstrate the importance of the people management area in the consummation of the organizational strategic planning. For these authors, the human resources area must be prepared to act as a strategic partner of the organization and not only be restricted to notary activities, such as the making of payroll, notes on functional changes, vacation control, admission and dismissal, among other activities.

For Barney (2002), Drucker (1991), Antunes and Martins (2005), Albuquerque (2009), Becker, Huselid and Hurich (2001), there are two essential measures that would indicate that the strategic alignment of the human resources area is consistent with the organizational strategy. The first concerns to the measurement of the performance of the sector through research whose results would serve to foster continuous improvement actions for the achievement of organizational objectives. The second refers to the distribution, by the human resources area, of responsibilities for the development of people to the other managers, instrumentalizing them to a new order and moving towards an integrated management focused on the business. That is, the responsibility for the development of people is no longer exclusive to the area of human resources and becomes systemic, interdependent and interactive, thereby demonstrating that the sector would be fully aligned with organizational strategic objectives. For these authors, the two measures are of singular importance in guiding the strategic alignment of the human resources area to the organizational strategy.

\subsubsection{Internal Strategic Alignment of the Area of Human Resources}

For Silveira (2015), Wall and Wall (1996) and Wood (1999), in the human resources area, internal alignment is directly related to the practice of people management. This involves organization culture, corporate values, supporting technology and the structure of the enterprise. Such a procedure requires articulation, harmony and tune 
between human resource management practices and organizational contingencies, which results in a people management policy aimed at meeting the specific objectives of strategic planning, facilitating the process of organizational cohesion.

Melo Neto and Froes (2001) and Dutra (2006), assert that the evolution of the people management area and the need for strategic alignment directed the area of human resources for a field hitherto not prioritized in this discipline: the field of social accountability, in which this area remained practically inert. The new organizational rationality required companies to include social responsibility as a strategic guideline, boosting actions aimed at the social objectives of all departments, including the human resources area. Internal social actions such as benefits, quality of life at work, environment and organizational climate, among others, are associated with external social actions called organizational citizenship, with intense participation by employees. Such measures raise the employees' personal self-esteem and, consequently, increase the quality, productivity and organizational competitiveness.

For the International Federation Of Accountants - IFAC (2013), a good model of people governance must relate criteria and standards that involve leadership management, ethical conduct, clear definition of the roles to be played by professionals, managers and partners, as well as their respective responsibilities, standardization of the human resources selection process, institutional communication, performance evaluation procedures, training and development, remuneration policies, retention practices and, above all, accountability.

In the United States, the Office of Personnel Management edited a document called The Human Capital Assessment and Accountability Framework - HCAAF (2005) establishing specific guidelines on the assessment structure and responsibilities of human capital in that country. This document determines the governance practices of people, including prohibited practices, notably based on the axes of strategic alignment, leadership and knowledge management, results-oriented culture, talent management and accountability. These are policies that must be implemented and practiced in an interrelated way in order to produce a unified workforce around the accomplishment of the organizational mission, offering goods and services of the highest quality and capable of adapting to the changing environment quickly and effective (HCAAF, 2005).

In view of the concepts covered in this topic, we sought to discuss the main concepts about strategy, strategy alignment with a focus on human resources performance and people management. The subjects covered allowed the construction of the methodology adopted in this research, whose model is presented in the following topic.

\section{Method and Procedures Applied to This Task}

This topic describes the method and the procedures used to achieve the results in accordance with the proposed objectives. The purpose is to demonstrate which methodological procedures have been used to design the research model and the scope of the intended results. The method used is the case study, designed to evaluate the event qualitatively and more thoroughly, considering that there is no way to obtain control over the studied phenomenon; thus follows Yin's (2009) indication when the author points out that this method serves to describe phenomena inserted in its own context, as prescribed by Yin (2009).

Seeking to specify the problem through bibliographic survey and a field research in which interviews were conducted with the target audience, therefore, it is an exploratory research. The study also describes the characteristics of the researched phenomenon, using a structured form to promote data collection, wherefore, the research is descriptive (GIL, 2008). The objective is to obtain and provide valid and reliable data and sufficient information to support a judgment on the different components of the set of specific activities which are or have been carried out in order to produce concrete results. Accordingly, the research is systematic, applied, planned and directed (LIMA, p. 23, 2000). The research also presents quantitative elements, considering that information was collected that enabled the comparison between one and another element, including the collection of data and the use of measures of quantifiable variables (BOUDON, 1989).

Regarding the procedures, the data collected were processed through a structured questionnaire using the Brazilian government's model called Programa GesPública (2005) as a reference; combined to the international standards applied to governance and strategic management of people in organizations adopted by the United States Government (Human Capital Assessment and Accountability Framework, 2005) and the study published by IFAC (Human Capital Public Sector: A Governing Body Perspective, 2013).

The collection of data was carried out in two stages. Firstly, questionnaires were given to those responsible for the People Management sector in the organizations surveyed. Secondly, technical visits were made to the units for validation (verification) and a better understanding of the data obtained in the first stage. Through the research 
questionnaire, the degree of efficiency of the Brazilian public administration in promoting the strategic alignment of people management with strategic organizational planning was investigated.

Based on the theoretical framework used, for the purposes of this paper, 11 (eleven) performance indicators were chosen in order to investigate whether the researched organizations apply the model and at what level of application of the measures aimed at the efficient alignment of human resources to the organizational strategy, explained in Table 1 below.

Table 1. Performance Indicators for verifying the efficiency in strategic alignment of human resources

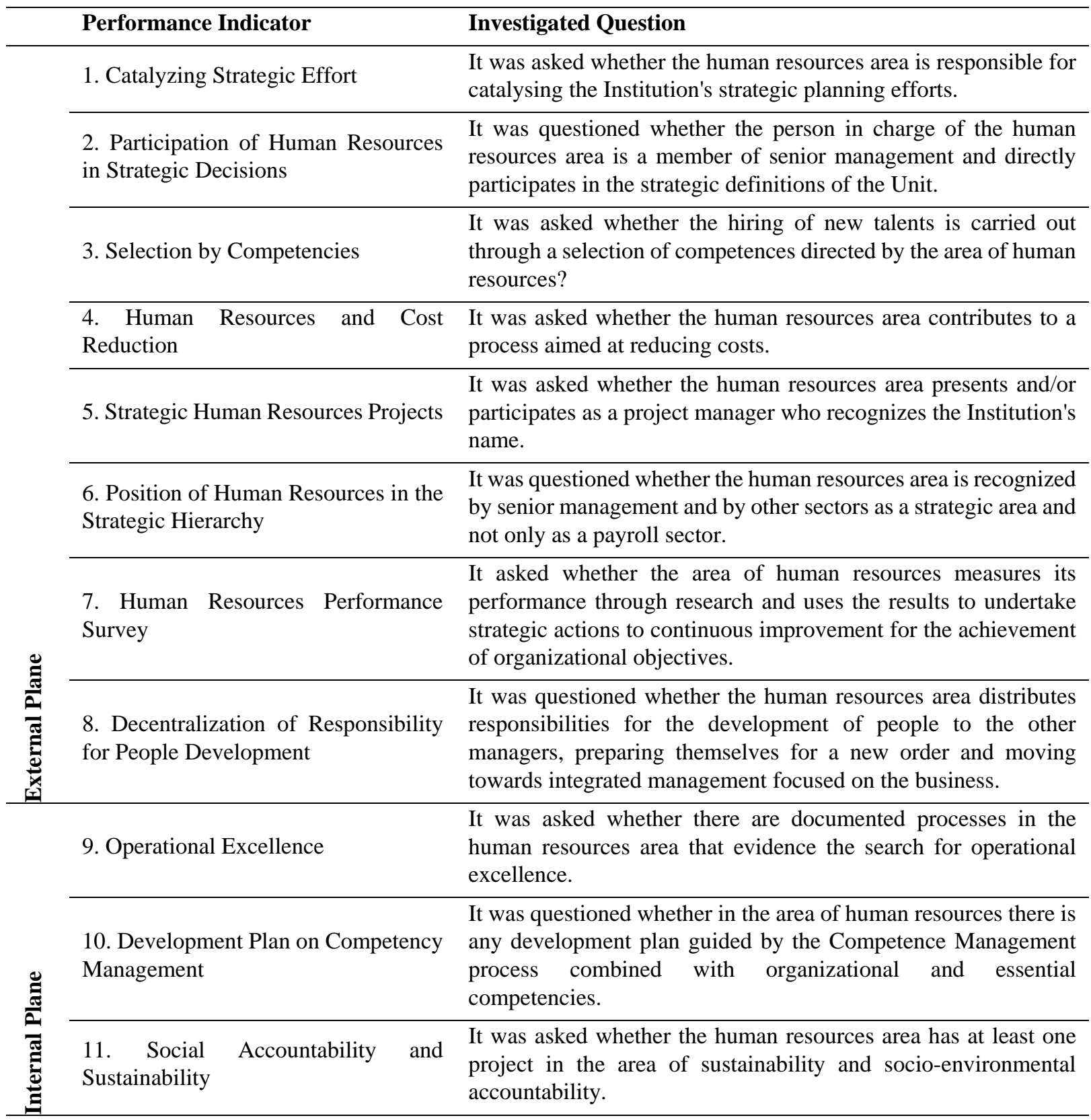

Source: Built by the author from the literature used in the research.

To carry out the research, 20 (twenty) units of the administrative structure of government of the State of Rondônia Brazil -, have been selected. As a limitation, it is relevant to note that it was not possible to carry out the research in all units of the aforementioned administrative structure, due to the lack of authorization to carry out the research in 
all of them. Notwithstanding this limitation, it did not affect the research work, since the quantitative participant represents $37 \%$ (thirty seven percent) of the total of units, which symbolizes a significant sample.

Using the data collected from the surveyed results, a mathematical model has been formulated calculated using the weighted average to measure the efficiency of public administration in promoting the strategic alignment of people management with strategic organizational planning. The proposed mathematical formulation is described below:

Matrix 1: It is the score (total of points) given to People Management Alignment to the Organizational Strategy, whose maximum score is 110 points, represented by the sum of the averages of the 11 indicatives (callsigns). It translates into the following formula:

$$
D_{a}=\sum_{i=1}^{q=11} M i
$$

Where:

$D_{a}$ : Score of the Alignment dimension;

$q$ : Quantity of dimension $D_{a}$ callsign;

$M_{i}$ : Average of callsign i;

$\mathrm{i}=1$ : First instalment to be added: dimension 1

Matrix 2: It is the average of each indicative. In all, 11 callsigns are calculated. It translates into the following formula:

$$
M_{i}=\frac{5}{3 q_{t}} \times\left[\frac{q_{i 1}}{2} \times\left(\frac{N_{i p 1}}{q_{i 1}}+\frac{N_{i r 1}}{q_{i 1}}+1\right)+q_{i 2} \times\left(\frac{N_{i p 2}}{q_{i 2}}+\frac{N_{i r 2}}{q_{i 2}}+1\right)+2 q_{i 3} \times\left(\frac{N_{i p 3}}{q_{i 3}}+\frac{N_{i r 3}}{q_{i 3}}+1\right)\right]
$$

Where:

$\mathrm{M}_{\mathrm{i}}$ : Average of callsign $\mathrm{i}$;

5/3: Constant for defining the weight of each phase (proposed, under implementation, implemented);

$\mathrm{q}_{\mathrm{t}}$ : Total number of units evaluated in each type of administration;

$\mathrm{q}_{\mathrm{i} 1}$ : Number of units with the indicative $\mathrm{i}$ in the proposal phase;

$1 / 2$ : Constant for defining the weight of each phase (proposed, under implementation, implemented);

$\mathrm{N}_{\mathrm{ip} 1}$ : Number of evidences of indicative $\mathrm{i}$ in the proposal phase;

$\mathrm{N}_{\mathrm{ir} 1}$ : Number of results of indicative $\mathrm{i}$ in the proposal phase;

$\mathrm{q}_{\mathrm{i} 1}$ : Quantity of units with indicative $\mathrm{i}$ in the proposal phase;

$\mathrm{N}_{\mathrm{ip} 3}$ : Number of evidences of the indicative i implemented;

$\mathrm{N}_{\mathrm{ir} 3}$ : Number of results of the indicative i implemented;

$\mathrm{q}_{\mathrm{i} 3}$ : Number of organs with the indicative i implemented;

$\mathrm{q}_{\mathrm{i} 2}$ : Number of organs with the indicative $\mathrm{i}$ in the implementation phase;

$\mathrm{N}_{\mathrm{ip} 2}$ : Number of evidences of indicative $\mathrm{i}$ in the implementation phase;

$\mathrm{N}_{\mathrm{ir} 2}$ : Number of results for indicative $\mathrm{i}$ in the implementation phase;

2: Constant to define the weight of each phase (proposed, under implementation, implemented);

To produce the results, the data was processed. The information collected in the bibliographic reference, in the evidence documents presented and, in the information, obtained from the target audience were considered, using the research questionnaire. From a qualitative point of view, we sought to assess in loco the conditions related to the object researched directly in Units selected.

For each factor evaluated, a closed answer was obtained on the topic. The answers given are as follows: (I) subject not known; (II) matter under proposal; (III) activity in the implementation phase; (IV) activity implemented; and (V) result obtained. For each question and in the case of an affirmative answer, evidence was requested such as: 
published reports, organizational climate survey carried out, laws, rules and regulations edited, etc. This requirement aimed to validate the responses obtained.

After inserting the data, the mathematical model was transported to an Excel spreadsheet from which it was possible to point out synthetically and quantitatively the performance of the researched organizations according to each indicator described in Table 1. Based on this information, it was defined to classify the Units into 6 (six) categories namely:

(I) INEXISTENT (INX): when the subject is unknown and, therefore, the efficiency index is at most 5\%;

(II) INADEQUATE (IND): when in the proposal phase the efficiency ratio varies from $1 \%$ to $20 \%$. This range shows that the organization already has some action in relation to efficiency management, but still to an inappropriate degree;

(III) INSUFFICIENT (INF): when in the proposal phase the efficiency index varies from $21 \%$ to $30 \%$. In this phase, it is considered that the administration already has more consistent proposals, but still in a scarce way, insufficient to meet the organizational purposes;

(IV) BEGINNER (ICT): when, in the proposal phase, the people governance index varies from $31 \%$ to $49 \%$. It is considered that, since then, management has initiated the procedures effectively and already has proven results of efficiency actions in strategic alignment;

(V) ACCEPTABLE (ACT): when in the implementation phase the efficiency ratio varies from $50 \%$ to $80 \%$. In this phase, it is considered that management already has considerable levels of efficiency, with effective results; and,

(VI) SATISFACTORY (SFT): when in the implemented phase, the efficiency ratio varies from $81 \%$ to $100 \%$. It represents the best result for the purposes of this research and indicates that the organization efficiently performs the strategic alignment of the human resources area with the strategic organizational planning. This operation resulted in the information shown in Table 2 below.

\section{Results and Discussion}

The results obtained in the survey are consolidated in Table 2 below:

Table 2. Public administration efficiency in HR alignment

\begin{tabular}{|c|c|c|c|c|c|c|c|c|c|c|c|c|}
\hline \multirow{2}{*}{ Indicators } & \multirow{2}{*}{$\mathrm{O}_{\mathrm{r}}$} & $A_{d}$ & \multicolumn{2}{|c|}{$\begin{array}{l}\text { a) Weight: } 0.83333 \\
\text { (Proposal phase) }\end{array}$} & \multicolumn{2}{|c|}{$\begin{array}{l}\text { b) Weight: } 1.66667 \\
\text { (implementation phase) }\end{array}$} & \multicolumn{2}{|c|}{$\begin{array}{l}\text { c) Weight: } 3.33333 \\
\text { (Implemented) }\end{array}$} & \multirow{2}{*}{$\mathrm{T}_{\mathrm{p}}$} & \multirow{2}{*}{$\mathrm{P}_{\mathrm{mp}}$} & \multirow{2}{*}{$\mathrm{a} \%$} & \multirow{2}{*}{$\mathrm{C}$} \\
\hline & & $\mathrm{Q}_{\mathrm{n}}$ & $\mathrm{Q}_{\mathrm{n}} \quad \mathrm{A}_{\mathrm{r}} \quad \mathrm{A}_{\text {and }}$ & $\mathrm{F}_{\mathrm{a}}$ & $\mathrm{Q}_{\mathrm{n}} \quad \mathrm{A}_{\mathrm{r}} \quad \mathrm{A}_{\text {and }}$ & $\mathrm{F}_{\mathrm{a}}$ & $\mathrm{Q}_{\mathrm{n}} \quad \mathrm{A}_{\mathrm{r}} \quad \mathrm{A}_{\text {and }}$ & $\mathrm{F}_{\mathrm{a}}$ & & & & \\
\hline 1. Catalyzing Strategic Effort & & 11 & & 0.00 & 1 & 0.08 & 8 & 0.67 & 2.4 & 10 & $24 \%$ & INF \\
\hline $\begin{array}{l}\text { 2. Participation of Human } \\
\text { Resources in Strategic } \\
\text { Decisions }\end{array}$ & & 15 & & 0.00 & & 0.00 & 5 & 0.42 & 1.4 & 10 & $14 \%$ & IND \\
\hline 3. Selection by Competencies & & 12 & 4 & 0.33 & & 0.00 & 4 & 0.33 & 1.4 & 10 & $14 \%$ & IND \\
\hline $\begin{array}{l}\text { 4. Human Resources and Cost } \\
\text { Reduction }\end{array}$ & 20 & 19 & & 0.00 & & 0.00 & 1 & 0.08 & 0.3 & 10 & $3 \%$ & INX \\
\hline $\begin{array}{l}\text { 5. Strategic Human Resources } \\
\text { Projects }\end{array}$ & & 10 & 2 & 0.17 & 2 & 0.17 & 6 & 0.75 & 2.9 & 10 & $29 \%$ & INF \\
\hline $\begin{array}{l}\text { 6. Position of Human } \\
\text { Resources in the Strategic } \\
\text { Hierarchy }\end{array}$ & & 16 & & 0.00 & & 0.00 & 4 & 0.33 & 1.1 & 10 & $11 \%$ & IND \\
\hline $\begin{array}{l}\text { 7. Human Resource } \\
\text { Performance Survey }\end{array}$ & & 15 & 2 & 0.17 & & 0.00 & 3 & 0.50 & 1.8 & 10 & $18 \%$ & IND \\
\hline
\end{tabular}




\begin{tabular}{|c|c|c|c|c|c|c|c|c|c|c|c|}
\hline $\begin{array}{l}\text { 8. Decentralization of } \\
\text { Responsibility for People } \\
\text { Development }\end{array}$ & 17 & 1 & 0.08 & 0.00 & 2 & & 0.17 & 0.6 & 10 & $6 \%$ & IND \\
\hline 9. Operational Excellence & 13 & 3 & 0.25 & 0.00 & 4 & 4 & 0.67 & 2.4 & 10 & $24 \%$ & INF \\
\hline $\begin{array}{l}\text { 10. Development Plan on } \\
\text { Competence Management }\end{array}$ & 14 & 4 & $0.33 \quad 1$ & 0.08 & 1 & 1 & 0.17 & 1.0 & 10 & $10 \%$ & IND \\
\hline $\begin{array}{l}\text { 11. Social Accountability and } \\
\text { Sustainability }\end{array}$ & & 1 & 0.08 & 0.00 & & & 0.00 & 0.1 & 10 & $1 \%$ & INX \\
\hline Total & & & & & & & & 15 & 110.0 & $14 \%$ & IND \\
\hline
\end{tabular}

Source: Built by the author from research data (2018).

Superscription:

$\mathrm{O}_{\mathrm{r}}=$ Number of units.

$A_{d}=$ Unknow subject.

$\mathrm{Q}_{\mathrm{n}}=$ Number of units that declared to be in the condition in relation to the indicative.

$\mathrm{A}_{\mathrm{ir}}=$ Provided proven results.

$A_{e}=$ They presented evidence supporting the statements.

$\mathrm{F}_{\mathrm{a}}=$ Scoring factor achieved in the respective phase.

$\mathrm{T}_{\mathrm{p}}=$ Total points achieved.

$\mathrm{P}_{\mathrm{mp}}=$ Maximum possible score.

a $\%=$ Percentage achieved in relation to the total possible points.

C - Classification: from 1 to 5\% INEXISTENT (INX); $6 \%$ to $20 \%$ INADEQUATE (IND); $21 \%$ to $30 \%$ INSUFFICIENT (INF); $31 \%$ to $49 \%$ BEGINNER (ICT); $50 \%$ to $80 \%$ ACCEPTABLE (ACT); $81 \%$ to $100 \%$ SATISFACTORY (SFT).

As per the data in Table 2, the question related to the strategic alignment and human resources to the organization's strategic planning, the following results were obtained: when asked if the area of human resources is responsible for catalysing the strategic planning efforts of the institution, obtained the following responses: 11 (eleven) units declared they did not know the subject; 1 (one) stated that the process is in the implementation phase (without proof); and 8 (eight) declared that the theme is implemented, but did not present evidence. In this item the score achieved was 2.4 points, which corresponds to the efficiency rate of $24 \%$ (Classification: Insufficient).

With regard to the participation of the human resources sector in strategic decisions (indicator 2), it was questioned whether the head of the sector is a member of senior management and participates directly in the strategic definitions of the Unit. These are the results: 15 (fifteen) institutions mentioned that they are unaware of the subject; and 5 (five) registered, without providing proof, that the practice is already adopted in their units. In this item, the score achieved was 1.4 points, corresponding to $14 \%$ efficiency ratio (Classification: Inadequate).

Related to the practice of selection by competencies (indicator 3), it was asked whether the hiring of new talents is carried out through the selection of competences directed by the area of human resources. It was found that: 12 (twelve) units affirm they do not know the subject; 4 (four) registered that the matter is in the proposal phase (without proof); and 4 (four) stated that the matter is implemented, without, however, presenting the supporting elements. In this item the score achieved was 1.4 points, which corresponds to the efficiency rate of $14 \%$ (Classification: Inadequate).

As for the contribution of the human resources area in some cost reduction process (indicator 4), it was verified whether the human resources area contributes to any process aimed at minimizing expenses in the organization. It was found that 19 (nineteen) institutions registered that they do not know the matter and only one (without presenting evidence) asserted that adopts the practice in its organization. In this item, the score achieved was 0.3 points, which corresponds to the efficiency rate of 3\% (Classification: Inexistent). 
Concerning to the existence of human resources projects aimed at extolling the Institution's name (indicator 5), it was questioned whether the human resources area presents, manages and/or participates in projects that recognized the Institution's name. The results were as follows: 10 (ten) units stated that they do not know the subject; 2 (two) said that they are in the proposal phase, without presenting proof; 2 (two) mentioned that there are projects in the implementation phase (without evidence); and 6 (six) registered that they adopt the practice, however, only 3 (three) units presented proof. In this item, the score achieved was 2.9 points, which corresponds to the efficiency rate of 29\% (Classification: Insufficient).

As for the position of the area of human resources in the Strategic hierarchy (indicator 6), it was asked whether the sector is recognized by senior management and by other sectors as a strategic area. The results showed that 16 (sixteen) units registered that they do not know the subject and 4 (four) declared that the subject is implemented, but did not present evidence. In this item the score achieved was 1.1, which corresponds to $11 \%$ efficiency (Classification: Inadequate).

In relation to conduction survey on the performance of human resources (indicator 7), it was questioned whether the area measures its performance through survey and use the results to undertake strategic actions for continuous improvement for the achievement of organizational goals. The results are as follows: 15 (fifteen) units declared that they do not; 2 (two) said that the matter is being proposed (without proving it); and 3 (three) asserted that the process is in place, having submitted proof of this statement. In this item, the score achieved was 1.8 points, which corresponds to $18 \%$ efficiency (Classification: Inadequate).

With regard to the decentralization of responsibility for the development of people (indicator 8), it was asked whether the human resources sector distributes responsibilities for the development of people to the other managers, becoming instrumental in a new order and moving towards an integrated management focused on business. It was found that 17 (seventeen) units declared to be unaware of the matter; 1 (one) informed that the matter is in the proposal phase (without proving it); and 2 (two), without proving it, reported that they adopt this practice. In this item the score achieved was 0.6 points, which corresponds to $6 \%$ efficiency ratio (Classification: Inadequate).

Regarding the existence of documented processes that evidence the search for operational excellence (indicator 9), it was verified whether there are documented processes that evidence the search for operational excellence. 13 (thirteen) institutions declared to be unaware of the matter; 3 (three) said that the theme is in the proposal phase, but they did not present proof; and 4 (four) mentioned that they already exercise this practice, having submitted the respective evidences. In this item, the score achieved was 2.4 points, which corresponds to the efficiency rate of $24 \%$ (Classification: Insufficient).

Concerning to the existence of a development plan guided by the competence management process (indicator 10), it was questioned whether there is a plan combined with organizational and essential competencies. It was found that 14 (fourteen) units declared they did not know the subject; 4 (four) asserted that the theme is in the proposal phase, but did not present evidence; 1 (one) unit declared that the process is being implemented; and 1 (one) said that the issue is implemented and provided proof. In this item, the score achieved was 1 point, which corresponds to the efficiency rate of $10 \%$ (Classification: Inadequate).

Finally, in relation to the existence of at least one project in the area of social accountability (indicator 11), it was asked whether the human resources sector has at least one project in the area of sustainability and social-environmental accountability. The results showed that 19 (nineteen) units declared that they are unaware of the subject and one unit declared that the theme is in the proposal phase (without presenting evidence of it). In this item, the score achieved was 0.1 points, which corresponds to an efficiency rate of $1 \%$ (Classification: Inexistent).

The sum of the results showed that the units totalled 15 (fifteen) of the 110 (one hundred and ten) possible points, which corresponds to the $14 \%$ efficiency index. According to the criteria established in this work, in relation to the strategic alignment of the human resources sector to the organization's strategic planning, these units were classified at the "inadequate" level.

The result indicates that the human resources sector of these units would not be aligned with the organizational strategy. If an efficient institutional strategic alignment with the people management area is an essential condition for the organization's success, it means that this success may be being affected.

As have been verified in the theoretical framework of this research, the competent strategic alignment of the human resources area with the organizational strategy is a fundamental factor for achieving corporate objectives and goals. If the management model is not aligned with the macro-strategy, it is very likely that the people management process 
is dissociated from the general guidelines of the institution and, in this case, it is only practicing notarial tasks, far from modern strategic management models, with losses for governance and public administration.

In addition to the damage to the processes and products generated by the institution, there are risks that human talent is being wasted due to its incorrect or incomplete application (such as loss to other market segments, excessive turnover, lack of commitment, low productivity, etc.). Ultimately, the most affected is the end user, that is, the citizen, whose expectation is always to receive more efficient public services. In confirming the tendency of the scenario presented here in the other units of public administration, it can be considered that people management in the public administration of that State is lagged in terms of efficiency in the management of human resources.

\section{Conclusion}

In this work, it was sought, through a field research supported by an appropriate bibliographic reference and by a specific mathematical formulation, to measure the efficiency of Public Administration in the process of strategic alignment of people management with the strategic organizational guidelines. For the development of the work, a theoretical path was traced and the selection of the participating units was carried out, distribution of the questionnaires, on-site visitation at the investigated institutions, material collection, data treatment and preparation of the research report.

The results showed that the Public Administration efficiency index in the process of strategic alignment of people management with the strategic organizational guidelines is $14 \%$ (fourteen percent). According to the parameters adopted in this study, the efficiency index was considering inadequate. As seen in this research, the inadequate efficiency in the strategic alignment process compromises the production capacity and inhibits the organization's competitive advantage. Such a situation may be causing loss or waste of resources and, consequently, losses to results. Based on this result, it is possible to conclude that the general objective of the research was achieved.

Regarding the specific objectives, it was found that the management partly adopts the model of strategic alignment of human resources with the organizational strategy. It was also possible to verify that the model is applied in an unstructured, unorganized and little disseminated way. It was not possible to identify effective policies definitively implemented, a situation that contributed to the low rate achieved. It is concluded, therefore, that the first specific objective of the research has been achieved.

Concerning to the second specific objective, it was found that, of the 11 (eleven) indicators analysed, 6 (six) were classified as inadequate, that is, the efficiency index varies from $1 \%$ to $20 \%$, which means that the administration until already has some action in relation to efficiency management, but still to an inappropriate degree. It was also verified that 3 (three) indicators were considered in the classification of insufficient, a level whose efficiency index varies from $21 \%$ to $30 \%$ and where it is considered that management already has more consistent proposals, but still in a scarce way, insufficient to meet organizational purposes. Finally, it was found that 2 (two) indicators demonstrate that there are no management actions regarding the participation of the human resources area in projects aimed at reducing costs and those focused at social accountability and sustainability. Thus, it is emphasized that the second specific objective of the research was also achieved.

Ultimately, as a third specific objective, it was sought to verify whether the human resources management practices exercised by the public administration are adequate to the strategic organizational alignment process. According to the theoretical framework on which this research is based, as well as the results obtained and shown in Table 2, it is concluded that the public administration does not direct appropriate actions to the strategic alignment of human resources to the organizational strategy. Wherefore, there is a satisfactory fulfilment of the third specific objective of the research.

It is noteworthy that the results presented do not have the power to represent, by themselves, the pure reality of the situation of the strategic alignment of the human resources area to the organizational strategy, especially because the indicators used do not include all the variables that interfere in the management of strategic alignment of human resources, with the need for greater and more specific enhancement on each indicator (to evaluate each unit independently, for instance) aimed at maturing the theme and improving the measurement model of the actions undertaken in the area of human resources in the public administration of the State of Rondônia. Nevertheless, it must be highlighted how significant the sample used in this study, which allows to infer its importance in academic and social context.

Lastly, it is emphasized that an inadequate strategic alignment causes human resources practices to occur in a way dissociated from the central strategy, which indicates a possible distortion of the measures adopted in relation to the 
achievement of the guidelines and strategic goals in these Public Units, a subject that can be deepened by other researches.

\section{References}

Albuquerque, L. G., Bosquetti, M. A., \& Parolim, S. R. H. (2009). A Integração Estratégica entre Inovação e Gestão de Pessoas. In L. G. Albuquerque, \& N. P. Leite (Eds.), Gestão de Pessoas - Perspectivas e Estratégias. Editora Atlas, São Paulo.

Andrews, K. R. (1971). The concept of corporate strategy. Homewood, IL: Dow Jones-Irwin.

Antunes, M. T. P., \& Martins, E. (2005). Gerenciando o Capital Intelectual: uma abordagem empírica baseada na Controladoria de grandes empresas brasileiras. In XII Congresso Brasileiro de Custos. Florianópolis.

Barney, J. (2002). Gaining and sustaining competitive advantage (2nd ed.). New Jersey: Prentice Hall.

Becker, B., Huselid, M., \& Hurich, D. (2001). Gestão Estratégica de Pessoas com Scorecard: intelrigando pessoas, estratégia e performance. Rio de Janeiro: Elsevier.

Beer, M., \& Eisenstat, R. A. (1996). Developing an organization capable of implementing strategy and learning. Human Relations, 49(5). https://doi.org/10.1177/001872679604900504

Boudon, R. (1989). Os métodos em Sociologia. Rio de Janeiro: Ática.

Collis, D. J. (1996). Organizational capability as a source of profit'in moingeon. B. et A.

Cristina, F. L. A. (2007). Conceitos, ferramentas e procedimentos. São Paulo: Atlas.

Davenport, T., \& Prusak, L. (1998). Conhecimento Empresarial: Como as Organizações Gerenciam o seu Capital Intelectual. Rio de Janeiro: Campus.

Decreto No 5.378 De 23 De Fevereiro De 2005. (2005). Institui o Programa Nacional de Gestão Pública e Desburocratização - GESPÚBLICA e o Comitê Gestor do Programa Nacional de Gestão Pública e Desburocratização, e dá outras providências. Brasília.

Drucker, P. F. (1999). Desafios gerenciais para o século XXI. São Paulo: Pioneira.

Dutra, J. S. (2006). Gestão de Pessoas: modelo, processos, tendências e perspectivas, 5. reimpr. São Paulo: Atlas.

Emílio, H. F. (2018). Balanced Scorecard e a Gestão Estratégica, Uma Abordagem Prática. Rio e Janeiro: Alta Books.

GIL. (2008). Antonio Carlos. Como elaborar projetos de pesquisa (4th ed.). São Paulo: Atlas, 2008.

HCAAF. (2005). The human capital assessment and accountability framework (HCAAF). Systems, standards and metrics. EUA, 2005. Retrieved from https://www.opm.gov/policy-data-oversight/human-capital-management/

Henderson, J. C. E., \& Venkatraman, N. (1996). Strategic alignment: Leveraging information technology for transforming organizations. IBM System Journal, 32(1), 4-16. https://doi.org/10.1147/sj.382.0472

IFAC. (2013). International Federation of Accountants. Good governance in the public sector: consultation draft for an international framework. Retrieved from https://www.ifac.org/publications-resources/good-governance-public-sector

Kaplan, R. S., \& Norton, D. P. (2017). Alinhamento, Utilizando o Balanced Scorecard Para Criar Sinergias Corporativas. Rio de Janeiro: Alta Books.

Labovitz, G., \& Rosansky, V. (1997). The power of alignment: How great companies stay centered and accomplish extraordinary things. John Wiley \& Sons, Inc.

Leme, F. M. T., \& Maria, F. R. (1998). Processo e relações do trabalho no Brasil. São Paulo: Atlas.

Lima, C. (2000). Avaliação das organizações de cuidados da saúde das pessoas com HIV/AIDS. Tese de Doutorado. Escola de Administração do Estado de São Paulo da Fundação Getulio Vargas. São Paulo, São Paulo, Brasil.

Neto, M., Francisco, de. P., \& César, F. (2001). Gestão da Responsabilidade social corporativa: o caso brasileiro. Rio de Janeiro: Qualitymark.

Peteraf, M., \& Reed, R. (2007). Managerial discretion and internal alignment under regulatory constraints and change. Strategic Management Journal, 28(11), 1089-1112. https://doi.org/10.1002/smj.628

Quinn, J. B. (2006). Estratégias para mudança. In Mintzberg, H., et al. (Eds.), O processo da estratégica: conceitos, contextos e casos selecionados (4th ed.). Porto Alegre: Bookman. 
SHRM (Society for Human Resource Management). (2007). The 2007-2008 workplace trends list: the top trends according to SHRM's Special Expertise Panels.

Silveira, V. N. S. (2015). Alinhamento estratégico e gestão estratégica de pessoas-análise conceitual e perspectivas teóricas. Revista Pretexto, 15(4), 114-133.

Trescastro, B. S. (2019). Gestão estratégica de pessoas no setor público. Belo Horizonte: Fórum.

Wall, S. J., Wall, S. R., \& Azevedo, C. (1996). Os novos estrategistas: criando líderes em todos os níveis da organização. Futura.

Wood, S. (1999). Getting the measure of the transformed high-performance organization. British Journal of Industrial Relations, 37(3), 391-417. https://doi.org/10.1111/1467-8543.00134

Yin, R. K. (2009). Case study research, design and methods (applied social research methods). Thousand Oaks. California: Sage Publications.

\section{Copyrights}

Copyright for this article is retained by the author(s), with first publication rights granted to the journal.

This is an open-access article distributed under the terms and conditions of the Creative Commons Attribution license (http://creativecommons.org/licenses/by/4.0/). 